\title{
Ongoing outbreak of mumps affecting adolescents and young adults in Bavaria, Germany, August to October 2010
}

W Otto ${ }^{1}$, A Mankertz ${ }^{2}$, S Santibanez ${ }^{2}$, H Saygili3 ${ }^{3}$, Wenzel ${ }^{4}$, W Jilg ${ }^{4}$, W F Wieland ${ }^{1}$, S Borgmann (Synlab@gmx.de) ${ }^{3}$

1. Department of Urology, St. Josef Hospital, University of Regensburg, Regensburg, Germany

2. National Reference Centre Measles, Mumps, Rubella, Robert Koch Institute, Berlin, Germany

3. Synlab Medical Care Service, Medical Care Centre Weiden, Weiden, Germany

4. Institute of Medical Microbiology and Hygiene, University of Regensburg, Regensburg, Germany

Citation style for this article:

Otto W, Mankertz A, Santibanez S, Saygili H, Wenzel J, Jilg W, Wieland WF, Borgmann S. Ongoing outbreak of mumps affecting adolescents and young adults in Bavaria, Germany, August to October 2010. Euro Surveill. 2010;15(50):pii=19748. Available online: http://www.eurosurveillance.org/ViewArticle. aspx?Articleld $=19748$

Article published on 16 December 2010

Since the introduction of a two-dose MMR vaccination regime the incidence of mumps virus infections has substantially declined. However, mumps outbreaks have recently been reported from several countries. Here we report an ongoing mumps outbreak in Germany. Between 1 July and 31 October, 115 infections have been laboratory-confirmed. Reported complications include one case of meningitis and 21 cases of orchitis, suggesting a high rate of complications. We suggest a vaccination campaign for young adults in northern Bavaria to limit severe mumps infections.

\section{Introduction}

Mumps virus infections may have a variable clinical outcome. Most commonly they lead to fever and parotitis. However, up to 30 per cent of male adolescent mumps cases develop orchitis. The German Standing Committee on Vaccination (Ständige Impfkommission, STIKO) recommends that children be vaccinated with two doses of MMR measles-mumps-rubella (MMR) or measles-mumps-rubella-varicella (MMRV) vaccine within their first two years of life (between 11 and 14 months and between 15 and 23 months) [1]. Mumps is not a notifiable disease in Germany, therefore information about mumps cases or outbreaks is scant. In other European countries, the introduction of a two-dose MMR vaccination regime resulted in a strong decline of the number of mumps virus infections [2-4]. However, resurgent outbreaks of mumps were recently reported from several European countries [2-11], the United States (US) and Canada [12-14]. Many of the outbreaks were seen in highly vaccinated populations, calling mumps virus vaccine efficiency into question [2-4, 6-9]. Here we report on an ongoing mumps outbreak in Germany.

\section{Methods}

The Synlab Medical Care Service Centre, Weiden, Bavaria, analyses laboratory samples from about 40 hospitals and more than 2,000 physicians serving outpatients predominantly from northern Bavaria [15]. In this study, results of serological mumps tests were evaluated. Data collected between January 2009 and October 2010 were examined. In total 1,248 serum samples were examined for IgM antibodies and 4,824 samples for IgG antibodies. More than $99 \%$ of these samples were derived from Bavarian patients.

Mumps antibody testing of patient sera was performed by using Enzygnost ELISA (anti-parotitis-virus/ IgM and anti-parotitis-virus/IgG, Siemens Healthcare Diagnostics Products, Marburg, Germany). Results of IgM ELISA were given as negative, borderline (equivocal), and positive. Results of IgG ELISA were given as negative ( $230 \mathrm{U} / \mathrm{ml}$ ), borderline (equivocal) (230 - $500 \mathrm{U} / \mathrm{ml}$ ), and positive $(>500 \mathrm{U} / \mathrm{ml})$. In the present analysis acute mumps infection was assumed when patients were IgM antibody positive or when patients either showed a borderline IgM antibody test result in combination with typical symptoms or had detectable mumps virus ribonucleic acid (RNA).

The German Reference Centre for measles, mumps and rubella virus at the Robert Koch Institut performed PCR analyses from either throat swabs and/or urine samples. The primers MuNP1 (5'- AGTGTACTAATCCAGGCTTG $\left.-3^{6}\right)$ and $C\left(5^{6}-\right.$ ACCCACCATTGCATAGTATC $\left.-3^{6}\right)$ were used to carry out complimentary deoxyribonucleic acid (cDNA) synthesis $\left(50^{\circ} \mathrm{C}, 30 \mathrm{~min} ; 95^{\circ} \mathrm{C}, 15 \mathrm{~min}\right)$ and the subsequent first round of a nested PCR at $30 x\left(94^{\circ} \mathrm{C}\right.$, $\left.30 \mathrm{sec} ; 52^{\circ} \mathrm{C}, 30 \mathrm{sec}, 72^{\circ} \mathrm{C}, 1 \mathrm{~min}\right)$ plus $10 \mathrm{~min} 72^{\circ} \mathrm{C}$. $\operatorname{MuNP}_{3}\left(5^{\circ}\right.$ - GTATGACAGCGTACGACCAAC - $\left.3^{\circ}\right)$ and MuNP4 $5^{\circ}$ - GATAGCAACCCCTGCCGTCT $-3^{\circ}$ for the second round $95^{\circ} \mathrm{C}, 5 \mathrm{~min}, 30 \times\left(94^{\circ} \mathrm{C}, 30 \mathrm{sec} ; 52^{\circ} \mathrm{C}, 30 \mathrm{sec}, 72^{\circ} \mathrm{C}\right.$, $1 \mathrm{~min})$. Genotyping of detected mumps virus was performed as recommended in the Proposal for genetic characterisation of wild-type mumps strains [16].

Clinical data from mumps patients with orchitis were recorded at the Department of Urology at the St. Josef Medical Centre in Regensburg. The department of urology is a facility of the University of Regensburg. 


\section{Results}

In the pre-outbreak period from January 2009 to June 2010 the number of patients infected with mumps virus was low (median per month $\mathrm{N}=1$ (range $0-$ 3)). However, this number has dramatically increased since the outbreak started. In July 2010 six patients tested positive for mumps IgM antibodies. In August 18 patients tested positive, in September 22 patients and in October 32 patients, respectively. Additionally, in August 2010 eleven patients exhibiting mumps infection symptoms had borderline IgM test results. In
September this number was eight and in October the number was 13.

Furthermore, positive PCR results were obtained from seven patients. Only two of the patients showed IgM antibodies while all PCR-positive patients exhibited IgG antibodies (median 14,000 U/ml). Genetic characterisation of mumps virus detected in the clinical material of seven cases revealed presence of genotype $G$.

\section{FIGURE}

Regional localisation of mumps virus infections in Bavaria, Germany, August-October 2010a
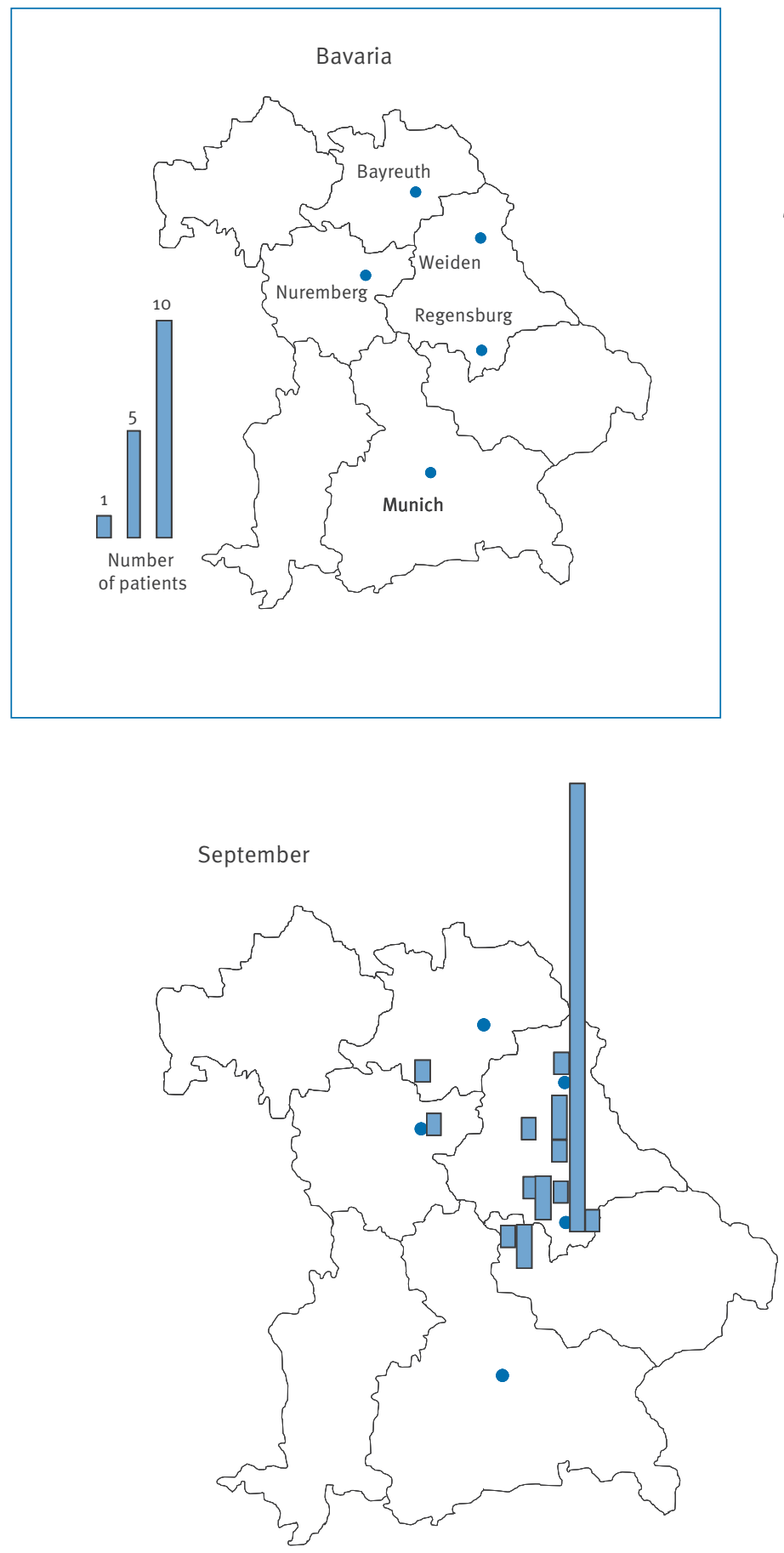

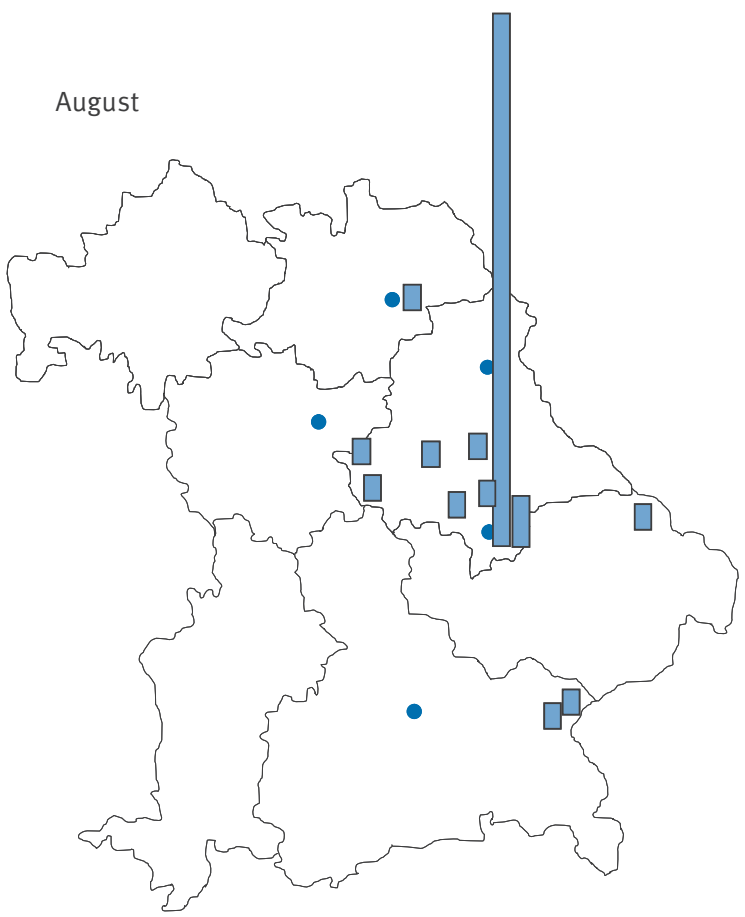

October

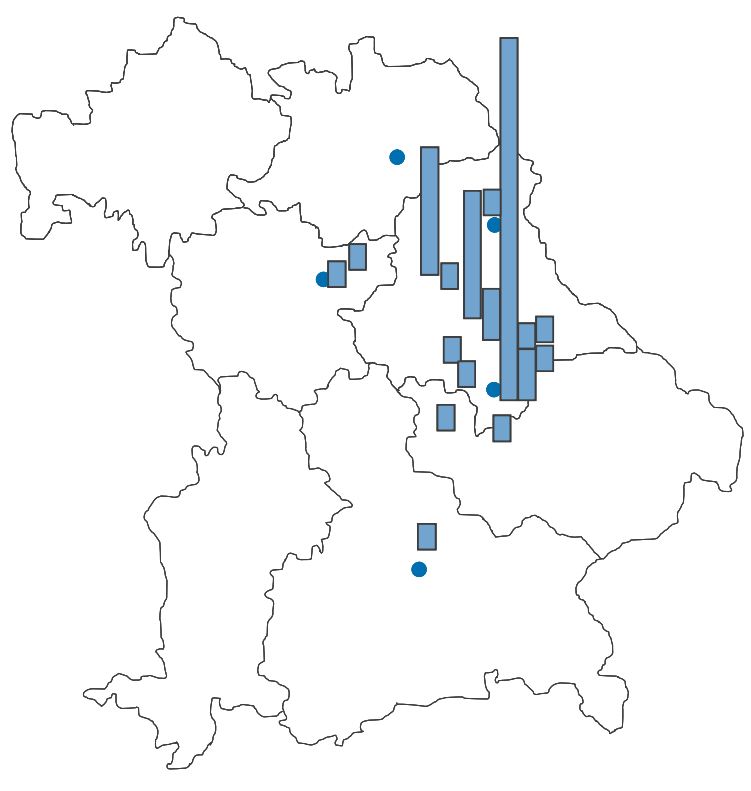

${ }^{a}$ The map shows the boundaries of the German federal state of Bavaria and boundaries of the Bavarian districts. Most cases were observed in Regensburg (southern Oberpfalz). Number of mumps cases per location is represented by the peaks of blue bars. 
In total 115 mumps infections were confirmed positive at the Weiden Synlab laboratory and at the Robert Koch Institute between 1 July and 31 October 2010. The median age was 24.5 years (mean 26.8 years, range 14-62 years). However, information on the vaccination status was available from only seven mumps patients. One of them was unvaccinated, one patient had received one dose of MMR and five patients had been vaccinated twice.

As illustrated in the Figure the majority of the infections occurred in the city of Regensburg (about 135,000 inhabitants) or in the surrounding area. This finding was most prominent in August while in September and October an increasing number of cases were noted in the region located northwest of Regensburg.

In August, one patient was diagnosed with mumps meningitis and a second case was suspected in November. In total 21 patients were treated at the St. Josef Hospital in Regensburg (median age 26 years) between July and October 2010, resulting in a total of 76 days of hospitalisation (Table).

\section{Discussion}

We give a preliminary description of an ongoing outbreak of mumps virus infection in northern Bavaria. Similarly to previous outbreaks in Austria, Luxembourg,
Ireland and the Netherlands, the present outbreak affects mainly young adult patients $[4,5,9,11]$.

We suppose that the actual number of affected patients is by far higher than 115 cases since certainly not every clinical case was confirmed in our laboratory.

Furthermore, the present case definition in Germany uses positive IgM antibody and/or positive PCR results [17]. Many patients with clinical symptoms displayed high IgG antibody titres probably due to prior immunisation or infection. As known from other viral diseases a viral re-infection is not necessarily accompanied by a rise in IgM antibodies but rather by an increase of IgG antibodies. Accordingly, during the outbreak months of July, August, September and October 2010, the median IgG titres were markedly higher than those observed in the previous months (January 2009-June 2010; data not shown). This supports the hypothesis that many mumps (re-)infections were accompanied by an increase of IgG antibody titre and not by the formation of IgM antibodies. This may have resulted in an underestimation in the number of mumps cases. Absence of mumps virus-specific IgM antibodies in the majority of the clinical cases, as determined in the current outbreak in Germany, is concordant with the laboratory data reported by the Centers for Disease Control and Prevention from an outbreak observed in a highly vaccinated population in the US [12].

\section{TABLE}

Clinical features of patients suffering from mumps orchitis, University Hospital of Regensburg, Germany July - October 2010



N.d.: Not determined.

a Body temperature $>38.5^{\circ} \mathrm{C}$.

${ }^{\mathrm{b}}$ Body temperature $37.5^{\circ} \mathrm{C}-38.5^{\circ} \mathrm{C}$. 
In contrast to Germany, mumps is a notifiable disease in Ireland and the Netherlands, where the collection of epidemiological data from many patients has been possible. In these populations the majority of the patients had been vaccinated and at least in the Dutch group most patients had been vaccinated twice [9]. Although we could get only limited information about vaccination status our data support the finding that most patients had been vaccinated completely indicating that complete vaccination does not prevent mumps infection in an outbreak situation with absolute certainty.

The current outbreak in Bavaria was caused by mumps virus genotype $\mathrm{G}$. Previous analyses have revealed that this genotype was associated with several mumps outbreaks in Europe and the US $[2,5,18,19]$. The possible emergence of a mutant strain of mumps virus has been reported under the selective pressure of immunisation with limited or no cross-protection induced by the vaccine strain [20]. A recent analysis indicated that individuals possessing low levels of neutralising antibodies may be at risk for breakthrough infections [21]. These findings underline the importance of investigating whether the current situation in Germany is due to a high degree of susceptible individuals or to a breakthrough of a currently circulating wildtype mumps virus.

In the present outbreak, predominantly young male patients have been affected. Complications as mumps orchitis have resulted in the hospitalisation of at least 13 young adult males.

The outbreak started in the city of Regensburg (about 135,000 inhabitants) and its surrounding area. In September and October an increasing number of cases was noted in the region located northwest of Regensburg. Due to very recent observations this trend also continued in November (data not shown) and it seems probable that the outbreak will soon reach the city of Nuremberg (about 500,000 inhabitants) and surroundings with 1.2 million inhabitants.

Measures taken by public health service in Luxembourg were recently proven to help confining a mumps outbreak among the military staff [5]. Furthermore a massvaccination successfully stopped a mumps outbreak in Austria [11]. Therefore it appears highly beneficial to initiate a vaccination campaign in northern Bavaria.

\section{Acknowledgements}

We are deeply grateful to Leigh-Sue Bachmann-Dietl from the Regensburg public health authorities for her excellent cooperation and to Heribert Gruber for critical reading the manuscript.

\section{References}

1. Robert-Koch-Institut. Empfehlungen der Ständigen Impfkommission (STIKO) am Robert Koch-Institut/Stand: Juli 2010. Epidemiol Bull. 2010;30:281-97.
2. Kuzmanovska G, Polozhani A, Mikik V, Stavridis K, Aleksoski B, Cvetanovska Z, et al. Mumps outbreak in the former Yugoslav Republic of Macedonia, January 2008-June 2009: epidemiology and control measures. Euro Surveill. 2010;15(23): pii=19586. Available from: http://www.eurosurveillance.org/ViewArticle. aspx?Articleld $=19586$

3. Slater PE, Anis E, Leventhal A. The control of mumps in Israel. Eur J Epidemiol. 1999;15(8):765-7.

4. Whyte D, O'Dea F, McDonnell C, O'Connell NH, Callinan $\mathrm{S}$, Brosnan E, et al. Mumps epidemiology in the mid-west of Ireland 2004-2008: increasing disease burden in the university/college setting. Euro Surveill. 2009;14(16): pii=19182. Available from: http://www.eurosurveillance.org/ ViewArticle.aspx?Articleld $=19182$

5. Mossong J, Bonert C, Weicherding P, Opp M, Reichert P, Even J, et al. Mumps outbreak among the military in Luxembourg in 2008: epidemiology and evaluation of control measures. Euro Surveill. 2009;14(7): pii=19121. Available from: http://www. eurosurveillance.org/ViewArticle.aspx?Articleld=19121

6. Roberts C, Porter-Jones G, Crocker J, Hart J. Mumps outbreak on the island of Anglesey, North Wales, December 2008-January 2009. Euro Surveill. 2009;14(5): pii=19109. Available from: http://www.eurosurveillance.org/ViewArticle. aspx?Articleld=19109

7. Sartorius B, Penttinen P, Nilsson J, Johansen K, Jönsson $\mathrm{K}$, Arneborn $\mathrm{M}$, et al. An outbreak of mumps in Sweden, February-April 2004. Euro Surveill. 2005;10(9): $\mathrm{pii}=559$. Available from: http://www.eurosurveillance.org/ViewArticle. aspx?Articleld $=559$

8. Stein-Zamir C, Shoob H, Abramson N, Tallen-Gozani E, Sokolov I, Zentner G. Mumps outbreak in Jerusalem affecting mainly male adolescents. Euro Surveill. 2009;14(50):pii=19440. Available from: http://www.eurosurveillance.org/ViewArticle. aspx?Articleld $=19440$

9. Whelan J, van Binnendijk R, Greenland K, Fanoy E, Khargi M, Yap K, et al. Ongoing mumps outbreak in a student population with high vaccination coverage, Netherlands, 2010. Euro Surveill. 2010;15(17):pii=19554. Available from: http://www. eurosurveillance.org/ViewArticle.aspx?Articleld=19554

10. Yung C, Bukasa A, Brown K, Pebody R. Public health advice based on routine mumps surveillance in England and Wales. Euro Surveill. 2010;15(38):pii=19669. Available from: http:// www.eurosurveillance.org/ViewArticle.aspx?Articleld=19669

11. Schmid D, Pichler AM, Wallenko H, Holzmann H, Allerberger F. Mumps outbreak affecting adolescents and young adults in Austria, 2006. Euro Surveill. 2006;11(24): pii=2972. Available from: http://www.eurosurveillance.org/ViewArticle. aspx?Articleld $=2972$

12. Centers for Disease Control and Prevention. Update: multistate outbreak of mumps-United States, January 1-May 2, 2006. MMWR Morb Mortal Wkly Rep. 2006;55(29):559-63.

13. Peltola H, Kulkarni PS, Kapre SV, Paunio M, Jadhav SS, Dhere RM. Mumps outbreaks in Canada and the United States: time for new thinking on mumps vaccines. Clin Infect Dis. 2007;45(4):459-66.

14. Anderson LJ and Seward JF. Mumps epidemiology and immunity: the anatomy of a modern epidemic. Pediatr Infect Dis J. 2008;27(10 Suppl):S75-9.

15. Borgmann S, Jakobiak T, Gruber H, Schröder H, Sagel U. Prescriptions of broad-spectrum antibiotics to outpatients do not match increased prevalence and antibiotic resistance of respiratory pathogens in Bavaria. Pol J Microbiol. 2009;58(2):105-10.

16. Jin L, Rima B, Brown D, Orvell C, Tecle T, Afzal M, Uchida K, Nakayama T, Song JW, Kang C, Rota PA, Xu W, Featherstone D. Proposal for genetic characterisation of wild-type mumps strains: preliminary standardisation of the nomenclature. Arch Virol. 2005;150(9):1903-9.

17. Robert-Koch-Institut. Falldefinitionen übertragbarer Krankheiten für den ÖGD: Krankheiten, für die gemäß LVO eine erweiterte Meldepflicht zusätzlich zum IfSG besteht (Stand 2009). Epidemiol Bull. 2009;5:33-49.

18. Health Protection Agency. [Internet]. Continued increase in mumps in universities 2008-2009. Health Protection Report. 2009;3(14),United Kingdom. Available from: http://www.hpa. org.uk/hpr/archives/2009/news1409.htm

19. Santak M, Kosutic-Gulija T, Tesovic G, Ljubin-Sternak S, Gjenero-Margan I, et al. Mumps virus strains isolated in Croatia in 1998 and 2005: Genotyping and putative antigenic relatedness to vaccine strains. J Med Virol. 2006;78(5):638-43.

20. Crowley B, Afzal MA. Mumps virus reinfection--clinical findings and serological vagaries. Commun Dis Public Health. 2002;5(4):311-3.

21. Rubin S, Mauldin J, Chumakov K, Vanderzanden J, Iskow $R$, Carbone K. Serological and phylogenetic evidence of monotypic immune responses to different mumps virus strains. Vaccine. 2006;24(14):2662-8. 